\title{
PROFIL MODEL MENTAL SISWA TENTANG LARUTAN ELEKTROLIT DAN NONELEKTROLIT
}

\author{
Ni Nyoman Junitri Suari ${ }^{1}$, I Nyoman Selamat ${ }^{2}$,I Wayan Suja ${ }^{3}$
}

${ }^{1}$ SMA Negeri 8 Denpasar 2,3Universitas Pendidikan Gnesha

\section{A R T I C L E I N F O}

Article history:

Received 20 April 2018

Received in revised form

15 October 2018

Accepted 12 October 2018

Available online 20 October 2018

\section{Kata Kunci:}

larutan elektrolit dan

nonelektrolit, model

mental, tes model mental.

\begin{abstract}
A B S T R A K
Penelitian ini merupakan penelitian kuantitatif yang bertujuan untuk mendeskripsikan profil model mental siswa tentang larutan elektrolit dan nonelektrolit di SMA Negeri 8 Denpasar. Penelitian menggunakan teknik survey di kelas X IPA dengan melibatkan 155 orang siswa. Pengumpulan data dilakukan dengan pemberian tes model mental berbentuk pilihan ganda dua tingkat (twotier test). Analisis data dilakukan dengan cara mengelompokan kemiripan jawaban siswa ke dalam tipe model mental tertentu. Hasil penelitian ini menunjukkan, bahwa profil model mental siswa kelas X IPA tentang larutan elektrolit dan nonelektrolit, sebanyak $12,85 \%$ tergolong model mental ilmiah dan $87,11 \%$ model mental alternatif, yang terdiri atas $63,85 \%$ benar sebagian, 19,63\% miskonsepsi khusus, dan 3,63\% tidak ada tanggapan. Dengan demikian, sebagian besar siswa belum memiliki model mental yang untuhuntuk memahami materi larutan elektrolit dan nonelektrolit.
\end{abstract}

\section{Pendahuluan}

Dalam mempelajari ilmu kimia, ada tiga level representasi yang perlu diperhatikan dan dipahami. Ketiga level representasi ini mencakup level makroskopik, level submikroskopis, dan level simbolik (Treagust dkk., 2003). Johnstone dalam Chittleborough (2004) menekankan pentingnya memulai pembelajaran kimia dari level makroskopis dan simbolik karena keduanya dapat divisualisasikan dan diilustrasikan dengan sebuah model. Level makroskopis merupakan fenomena kimia yang dapat secara langsung diamati dan dapat dirasakan dengan panca indera. Nelson dalam Chittleborough (2004) menyatakan level submikroskopis adalah level paling sulit karena menjelaskan fenomena makroskopis pada level submikroskopis (atom, ion, atau molekul). Level submikroskopis tidak dapat dilihat secara langsung, komponennya sulit diterima sebagai sesuatu yang nyata.

Johnstone dalam Chittleborough (2004) telah membagi representasi dalam mempelajari ilmu kimia, yaitu level makroskopis, level submikroskopis dan level simbolik yaitu: (1) Level makroskopis adalah sesuatu yang nyata dan secara langsung atau tidak langsung merupakan bagian dari pengalaman sehari-hari. (2) Level submikroskopis adalah fenomena kimia yang nyata tetapi masih memerlukan teori untuk menjelaskan apa yang terjadi pada tingkat molekuler dan menggunakan representasi model teoritis. (3) Level simbolik adalah representasi dari suatu kenyataan bisa berupa gambar, simbol atau rumus.

Model mental merupakan representasi intrinsik berupa objek, ide, atau proses yang muncul selama berlangsung proses kognitif untuk memberikan alasan, menggambarkan, menjelaskan, atau memprediksi sebuah fenomena (Wang, 2007). Menurut Coll \& Treagust dalam Wang (2007) model mental dibagi tiga tipe, yaitu: model mental ilmiah, model mental konseptual, dan model mental alternatif. Model mental ilmiah, yaitu model mental yang telah melalui pengujian eksperimental yang ketat, yang dipublikasikan dalam literatur ilmiah dan diterima secara luas oleh komunitas ilmiah. Sedangkan, model yang tepat dan koheren yang dibuat oleh guru atau dosen untuk tujuan pembelajaran disebut model mental konseptual. Model konseptual yang diperkenalkan pengajar di dalam kelas akan dimodifikasi berdasarkan pengetahuan pribadi yang mereka miliki dan model ini bersifat pribadi yang disebut model mental alternatif.

\footnotetext{
1 Corresponding author.

E-mail : juni329suari@gmail.com (Ni Nyoman Junitri Suari),
} 
Tujuan dari penelitian ini adalah untuk mendeskripsikan dan menjelaskan model mental siswa kelas X IPA SMAN 8 Denpasar tentang larutan elektrolit dan nonelektrolit

\section{Metode}

Penelitian ini dilaksanakan di SMA Negeri 8 Denpasar pada semester genap tahun ajaran 2017/2018. Sampel dalam penelitian adalah siswa kelas X IPA sebanyak 155 orang. Penelitian dirancang mulai dari tahap: (1) penyusunan instrument, (2) validasi instrument, (3) uji coba instrument, (4) pengumpulan data, (5) analisis data hasil penelitian, serta (6) pelaporan. Instrumen yang digunakan dalam penelitian ini adalah tes model mental yang diadaptasi dari pengembangan oleh Suja (2018), berbentuk pilihan ganda dua tingkat (two-tier test), terdiri dari dua bagian, yaitu bagian pertama berisikan pilihan jawaban (level makroskopis) yang telah disediakan berkaitan dengan konten, sedangkan pada bagian kedua pelajar dituntut untuk memberikan alasan/argumentasi (level submikroskopis dan level simbolik) atas jawaban bagian pertama. Model mental siswa dikelompokkan berdasarkan kemiripan jawaban siswa ke dalam tipe model mental tertentu. Dalam penelitian ini, model mental dikelompokkan ke dalam empat tipe, yaitu: tidak ada jawaban/tanggapan (No Response/NR), miskonsepsi khusus pada bagian tertentu (Specific Misconceptions/SM), benar sebagian (Partially Correct/PC), dan benar secara ilmiah (Scientifically Correct/SC) (Sendur, dkk., 2010). Selanjutnya, tiga model mental pertama secara umum disebut sebagai model mental alternatif, sedangkan model mental keempat dilabel sebagai model ilmiah atau model konseptual

\section{Hasil dan pembahasan}

Berdasarkan hasil penelitian, diperoleh profil model mental siswa kelas X IPA di SMA Negeri 8 Denpasar tentang larutan elektrolit dan nonelektrolit seperti pada Tabel 1

Tabel 1. Profil Model Mental Siswa Kelas X IPA di SMA Negeri 8 Denpasar tentang Larutan Elektrolit dan Nonelektrolit

\begin{tabular}{|c|c|c|c|c|c|c|c|c|c|}
\hline \multirow[t]{2}{*}{ NS } & \multirow[b]{2}{*}{ Indikator } & \multicolumn{8}{|c|}{ Model Mental } \\
\hline & & SC & \% SC & PC & $\%$ PC & SM & $\begin{array}{c}\% \\
\text { SM }\end{array}$ & NR & $\begin{array}{c}\% \\
\text { NR }\end{array}$ \\
\hline 1 & $\begin{array}{l}\text { Mengidentifikasi ciri-ciri } \\
\text { larutan elektrolit jika dialiri } \\
\text { arus listrik }\end{array}$ & 22 & 15,71 & 133 & 84,28 & 0 & 0,00 & 0 & 0,00 \\
\hline 2 & $\begin{array}{l}\text { Mengidentifikasi ciri-ciri } \\
\text { larutan elektrolit jika dialiri } \\
\text { arus listrik }\end{array}$ & 13 & 9,28 & 111 & 70,71 & 31 & 20,00 & 0 & 0,00 \\
\hline 3 & $\begin{array}{l}\text { Menentukan senyawa } \\
\text { elektrolit atau nonelektrolit } \\
\text { berdasarkan daya hantar } \\
\text { listriknya. }\end{array}$ & 3 & 2,14 & 131 & 85,71 & 21 & 12,14 & 0 & 0,00 \\
\hline 4 & $\begin{array}{l}\text { Menentukan senyawa } \\
\text { elektrolit atau nonelektrolit } \\
\text { berdasarkan daya hantar } \\
\text { listriknya. }\end{array}$ & 8 & 5,71 & 100 & 65,00 & 47 & 29,28 & 0 & 0,00 \\
\hline 5 & $\begin{array}{l}\text { Memprediksi daya hantar } \\
\text { listrik cairan senyawa ionic } \\
\text { atau kovalen polar }\end{array}$ & 11 & 7,85 & 93 & 57,85 & 46 & 31,42 & 5 & 2,85 \\
\hline 6 & $\begin{array}{l}\text { Memprediksi daya hantar } \\
\text { listrik cairan senyawa ionic } \\
\text { atau kovalen polar }\end{array}$ & 27 & 19,28 & 81 & 51,42 & 39 & 25,71 & 8 & 3,57 \\
\hline 7 & $\begin{array}{l}\text { Menjelaskan daya hantar } \\
\text { listrik kristal garam }\end{array}$ & 11 & 7,85 & 93 & 60,00 & 42 & 27,14 & 9 & 5,00 \\
\hline 8 & $\begin{array}{l}\text { Menganalisis daya hantar } \\
\text { listrik larutan yang } \\
\text { mengandung beberapa } \\
\text { komponen zat terlarut }\end{array}$ & 23 & 16,42 & 94 & 57,85 & 27 & 17,85 & 11 & 7,85 \\
\hline
\end{tabular}




\begin{tabular}{|c|c|c|c|c|c|c|c|c|c|}
\hline 9 & $\begin{array}{l}\text { Menyimpulkan daya hantar } \\
\text { listrik larutan yang } \\
\text { mengandung beberapa } \\
\text { komponen zat terlarut }\end{array}$ & 28 & 20,00 & 64 & 36,42 & 46 & 32,85 & 17 & 10,71 \\
\hline 10 & $\begin{array}{l}\text { Menyimpulkan jenis larutan } \\
\text { berdasarkan daya hantar } \\
\text { listrik dan derajat } \\
\text { keasamannya }\end{array}$ & 34 & 24,28 & 109 & 69,28 & 0 & 0,00 & 12 & 6,42 \\
\hline & Total & 180 & 12,85 & 1009 & 63,85 & 299 & 19,63 & 62 & 3,63 \\
\hline
\end{tabular}

Data hasil tes dan profil model mental siswa kelas X IPA di SMA Negeri 8 Denpasar tentang larutan elektrolit dan nonelektrolit pada Tabel 1 menunjukkan, bahwa 12,85\% konsep-konsep kimia dipahami oleh siswa dalam bentuk model mental ilmiah dan $87,11 \%$ dalam bentuk model mental alternatif. Model mental alternatif tersebut terdiri dari 63,85\% model mental benar sebagian, 19,63\% model mental miskonsepsi khusus, dan 3,63\% tidak ada tanggapan. Persentase model mental tidak ada tanggapan tertinggi, yaitu $10,71 \%$, tentang daya hantar listrik oralit dan air seni manusia. Persentase model mental miskonsepsi khusus tertinggi, yaitu 32,85\%, tentang daya hantar listrik air seni manusia. Model mental benar sebagian memiliki persentase tertinggi $85,71 \%$ tentang daya hantar listrik urea. Data profil model mental siswa berdasarkan persentase masing-masing kategori model mentalnya dapat disajikan dalam bentuk diagram pie pada Gambar 1.

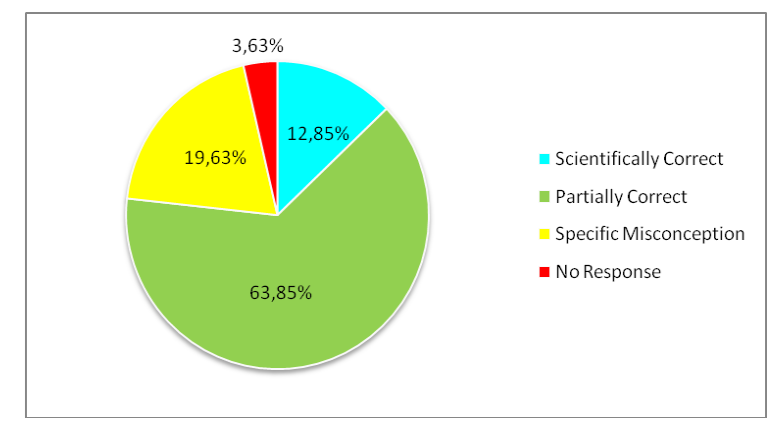

Gambar 1 Diagram Pie Profil Model Mental Siswa Berdasarkan Persentase Masing-Masing Model Mental

Terkait pemahaman siswa tentang ciri-ciri larutan elektrolit jika dialiri arus listrik, sesuai dengan indikator 1, sebagian besar siswa memiliki model mental benar sebagian. Kondisi itu disebabkan siswa mengetahui tentang ciri-ciri larutan elektrolit, tetapi tidak memahami proses yang terjadi pada tingkat partikel materi. Selain itu, sebagian siswa mengalami miskonsepsi karena menganggap semua senyawa yang bersifat polar dapat menghantarkan arus listrik dan dapat terionisasi dalam air karena sama-sama polar. Secara konseptual etanol yang termasuk senyawa polar tidak dapat terionisasi di dalam air. Senyawa tersebut di dalam air hanya terurai menjadi molekul-molekulnya. Larutan etanol tidak mampu menghantarkan arus listrik karena tidak mengandung ion-ion.

Indikator 2 tentang penentuan senyawa elektrolit dan nonelektrolit berdasarkan daya hantar listriknya. Sebagian besar siswa memiliki model mental benar sebagian. Hal ini disebabkan siswa dapat menentukan senyawa yang dapat menghantarkan arus listrik dan senyawa yang tidak dapat menghantarkan arus listrik. namun siswa belum mampu menjelaskan dengan benar bagaimana urea tidak dapat menghantarkan arus listrik. Siswa hanya mengetahui ciri-ciri urea, seperti mengandung unsur karbon, hidrogen dan oksigen. Sebagian siswa mengalami miskonsepsi karena menganggap amoniak tidak dapat menghantarkan arus listrik dan tidak terionisasi sehingga termasuk larutan nonelektrolit. Secara keilmuan urea di dalam air tidak dapat menghantarkan arus listrik karena terurai menjadi molekulmolekulnya dan terhidrasi oleh molekul-molekul air, serta urea bersifat netral (sesuai dengan derajat keasaman). Urea dapat terurai didalam air dengan reaksi $\mathrm{CO}\left(\mathrm{NH}_{2}\right)_{2(s)}+\mathrm{H}_{2} \mathrm{O}_{(\mathrm{ll})} \rightarrow \mathrm{CO}\left(\mathrm{NH}_{2}\right)_{2(a q)}$.

Terkait dengan pemahaman siswa mengenai daya hantar listrik cairan senyawa ionik atau kovalen polar terdapat pada indikator 3, sebagian besar siswa memiliki model mental benar sebagian. Hal ini disebabkan siswa mampu menentukan suatu senyawa termasuk larutan elektrolit dan nonelektrolit, serta mengetahui senyawa tersebut termasuk kovalen polar, tetapi tidak memahami proses yang terjadi pada tingkat partikel materi. Selain itu, terdapat siswa yang mengalami miskonsepsi karena menganggap 
semua senyawa yang berbentuk cairan dapat menghantarkan arus listrik karena senyawa tersebut akan terurai didalam air. Secara keilmuan, senyawa seperti asam sulfat cair dan asam flourida termasuk senyawa molekular (terdiri atas molekul-molekul) dan tidak terionisasi dalam cairannya. Karena tidak mengandung ion-ion, maka senyawa tersebut tidak dapat menghantarkan arus listrik.

Indikator 4 tentang daya hantar listrik kristal garam. Model mental benar sebagian dimiliki oleh sebagian besar siswa. Siswa mengetahui bahwa kristal garam dapur tidak dapat menghantarkan arus listrik, tetapi siswa tidak memahami argumentasinya pada tingkat partikel materi. Selain itu, siswa mengalami miskonsepsi karena keliru dalam mengartikan wujud kristal garam dapur. Siswa menganggap kristal garam dapur dapat menghantarkan arus listrik dengan kuat dan ada pula siswa yang menganggap bahwa kristal garam dapur termasuk asam kuat dan dapat menghantarkan arus listrik. Kekeliruan tersebut menandakan siswa tidak memahami bagaimana pengaruh wujud suatu senyawa dalam menentukan daya hantar listriknya. Selain itu, kekeliruan dalam menggambarkan model kristal garam dapur juga terjadi pada siswa. Banyak siswa hanya menuliskan ion-ion garam dapur,yaitu $\mathrm{Na}^{+}$dan $\mathrm{Cl}$. Secara konseptual, kristal garam dapur berupa padatan jika diuji tidak menghantarkan arus listrik. Hal ini disebabkan ion-ion $\mathrm{Na}^{+}$dan $\mathrm{Cl}^{-}$pada kristal garam dapur tersusun sangat rapat sehingga tidak dapat bergerak bebas.

Pengetahuan siswa mengenai daya hantar listrik larutan yang mengandung beberapa komponen zat terlarut, terdapat pada indikator 5 . Model mental benar sebagian dimiliki oleh sebagian besar siswa. Hal ini disebabkan siswa mengetahui bahwa oralit dan air seni manusia termasuk larutan elektrolit dan mengandung garam dapur, tetapi tidak memahami proses yang terjadi pada tingkat partikel materi. Selain itu, sebagian siswa mengalami miskonsepsi karena menganggap semua komponen zat terlarut yang dominan pada larutan akan mempengaruhi daya hantar listrik. Siswa menganggap bahwa air seni tidak dapat meghantarkan arus listrik karena urea dan air lebih dominaan. Secara keilmuan air seni manusia mengandung ion natrium, ion kalium, klorida, magnesium, kalsium, ammonium, sulfat, dan fosfat yang mampu menghantarkan arus listrik, demikian pula oralit termasuk elektrolit kuat yang dapat terionisasi sempurna menghasilkan ion-ion natrium dan klorida.

Indikator 6 tentang menyimpulkan jenis larutan berdasarkan daya hantar listrik dan derajat keasamannya. Pada indikator tersebut sebagian besar siswa memiliki model mental benar sebagian. Siswa memahami bahwa air laut merupakan larutan elektrolit kuat, tetapi sebagian besar siswa hanya mengetahui bahwa air laut mengandung garam yang dapat menghantarkan arus listrik dengan baik, tetapi tidak memahami proses yang terjadi pada tingkat partikel materi. Secara konseptual, air laut bersifat elektrolit kuat karena mengandung banyak ion yang mampu bergerak bebas menuju elektroda. Ion-ion tersebut dapat menghantarkan arus listrik.

Berdasarkan pemaparan diatas model mental kimia siswa sebagian besar tergolong model mental alternatif, dengan persentase 63,85\% yang tergolong model mental benar sebagian (PC). Temuan tersebut sejalan dengan hasil penelitian Suja (2015), Susanty (2011), Sucitra (2016), Okvasari (2014), Handayanti (2015), dan Pujiasih (2018), yang mendapatkan sebagian besar model mental siswa ada dalam bentuk model mental alternatif. Kondisi itu disebabkan siswa tidak mampu membangun interkoneksi tiga level kimia karena rendahnya pemahaman pada level submikroskopis.

\section{Simpulan dan saran}

Berdasarkan hasil penelitian ini dapat disimpulkan, bahwa profil model mental siswa kelas X SMA Negeri 8 Denpasar tentang larutan elektrolit dan nonelektrolit mencakup 12,85\% tergolong model mental ilmiah (scientifically correct), serta $87,11 \%$ model mental alternatif, yang terdiri atas $63,85 \%$ model mental benar sebagian (partially correct); 19,63\% miskonsepsi khusus (specific misconceptions); dan $3,63 \%$ tidak ada tanggapan (no response). Data tersebut menunjukkan siswa belum memiliki pengetahuan yang tentang utuh larutan elektrolit dan nonelektrolit.

\section{Daftar Rujukan}

Chittleborough, G. 2004. The Role of Teaching Models and Chemical Representations In Developing Student's Mental Model of Chemical Phenomena. Thesis. Perth: Curtin University of Technology.

Handayani. 2015. Analisis Profil Model Mental Mental Siswa SMA pada Materi Laju Reaksi. Jurnal

Penelitian dan Pembelajaran IPA,1(1). Diambil
http://jurnal.untirta.ac.id/index.php/JPPI/article/view/329.(19 September 2017)

Okvasari, R. 2014. Profil Model Mental Siswa SMA Pada Materi Sistem Koloid. Skripsi. Universitas

Pendidikan Indonesia. Diambil dari: http://repository.upi.edu/14310/. (19 September 2017)

Pujiasih, R. 2018. Profil Model Mental Siswa SMA Negeri Bali Mandara tentang Senyawa Hidrokarbon. Skripsi. Universitas Pendidikan Ganesha. 
Sendur, G., Toprak, M., \& Pekmez, E. 2010. Analyzing of Students' Misconceptions About Chemical Equilibrium.Makalah disajikan pada International Conference on New Trends in Education and Their Implications, Antalya (Turkey).

Sucitra, I. G. N. B. 2016. Profil Model Mental Siswa tentang Korelasi Struktur Molekul terhadap Sifat Senyawa Organik. Skripsi. Universitas Pendidikan Ganesha Singaraja.

Suja, I W. 2015. Model Mental Mahasiswa Calon Guru Kimia dalam Memahami Bahan Kajian Stereokimia. Jurnal Pendidikan Indonesia, 4(2), 625-638.

Susanty, P. 2011. Profil Model Mental Siswa pada Pokok Bahasan Larutan Elektrolit dan Nonelektrolit. Skripsi. Bandung: UPI. Diambil dari: http://aresearch.upi.edu/skripsiview.php?no_skripsi=5460. (21 September 2017)

Treagust, D. F., Chittleborough G, \& Mamiala T., 2003 The Role of Submicroscopic and Symbolic Representations in Chemical Education. International Journal of Science Education, 25(11):1353-1368.

Wang, C. Y. 2007. The Role of Mental-Modelling Ability, Content Knowledge, and Mental Model in General Chemistry Students' Understanding About Moleculer Polarity. Disertasi tidak dipublikasikan. Columbia: University of Missouri. 